\title{
SECTION 1557 OF THE AFFORDABLE CARE ACT: AN \\ EFFECTIVE MEANS OF COMBATTING HEALTH INSURERS' DISCRIMINATION AGAINST INDIVIDUALS WITH HIV/AIDS?
}

\author{
Spenser G. Benge*
}

I. INTRODUCTION. .194

A. A Quick Breakdown of the ACA. 195

1. Health Insurance Exchanges .............................. 196

2. The Individual Mandate.................................... 196

3. Premium Tax Credits ....................................... 197

4. The Guaranteed Issue Requirement ................... 198

5. The Community Rating Requirement................. 198

B. The Post-ACA Landscape: Three

Insurance Practices ................................................. 198

C. Section 1557 of the ACA ........................................ 201

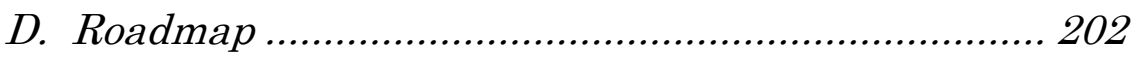

II. The Three Discriminatory Health Insurance

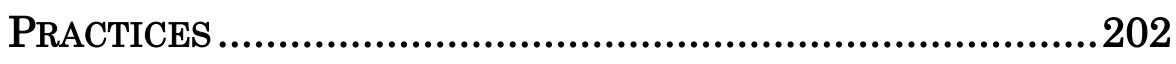

A. The Nature and Standard of Care for Treating. HIVIAIDS......................................................... 203

B. The Detrimental Effects of These Three Aforementioned Practices on Individuals with HIVIAIDS ........................................................ 204

1. High Tiering ....................................................... 205

2. Step therapy requirements................................. 207

3. Pre-authorization requirements.......................... 208

III. COVERED ENTITIES UNDER § 1557 ...............................208

A. "Federal Financial Assistance"............................... 209

B. "Program or Activity"............................................ 213 
C. Putting It Together ........................................... 214

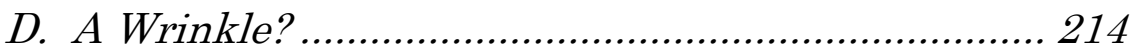

E. Other Means of $\mathcal{S} 1557$ Coverage........................... 216

IV. HIGH TIERING AND STEP-THERAPY AND PREAUTHORIZATION REQUIREMENTS: DISCRIMINATORY AND PROHIBITED UNDER § 1557?...........................................217

A. What Type of Discrimination is Prohibited

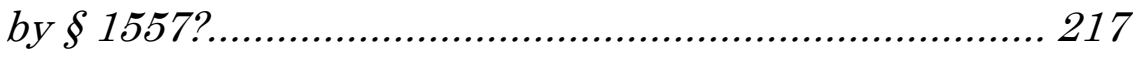

B. Intentional Discrimination: Prohibited?................. 218

C. High Tiering and Step-Therapy and

Pre-Authorization Requirements: Intentional

Discrimination?... 219

1. Preliminary Question 1: Are These Three

Insurance Practices Discriminatory to Begin With? 219

2. Preliminary Question 2: Do Insurance

Companies Have Autonomy in Choosing to Adhere to These Practices? 221

3. Are Health Insurance Companies that are Adhering to These Practices Exhibiting Intentional Discrimination? ................................... 221

D. Disparate Impact Discrimination: Prohibited? ..... 227

E. High Tiering and Step-Therapy and

Pre-Authorization Requirements: Disparate

Impact Discrimination?. 228

V. A Policy Consideration...........................................230

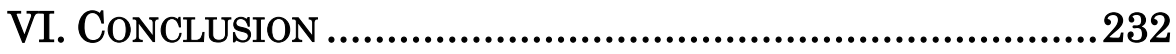

\section{INTRODUCTION}

Before the passage of the Affordable Care Act ("ACA"), health insurers either completely refused to provide coverage 
to individuals with a preexisting condition, ${ }^{1}$ or charged such individuals grossly higher rates for coverage than those without a preexisting condition. ${ }^{2}$ Because HIV/AIDS qualifies as a preexisting condition, ${ }^{3}$ these insurance practices have historically applied to individuals with HIV/AIDS. However, the passage of the ACA changed that landscape. But before proceeding further with an explanation of the current landscape, a brief look at some of the key components of the ACA is necessary.

\section{A. A Quick Breakdown of the ACA}

The broad purpose of the ACA is to expand health insurance to make it accessible to more Americans. ${ }^{4}$ The ACA accomplishes this goal with five main mechanisms: (1) health insurance exchanges, ${ }^{5}$ also referred to as health insurance marketplaces, (2) the individual mandate, ${ }^{6}$ (3) premium tax credits, ${ }^{7}$ (4) the guaranteed issue requirement, ${ }^{8}$ and (5) the community rating requirement. ${ }^{9}$

* J.D. Candidate, 2016, Indiana University Robert H. McKinney School of Law; B.S., 2013, Indiana University - Bloomington.

1 Mark Bolin, The Affordable Care Act and People Living with HIVIAIDS: A Roadmap to Better Health Outcomes, 23 ANNALs HEALTH L. 28, 40-41 (2014); The Affordable Care Act and HIV/AIDS, AIDS.GOV, https://aids.gov/federal-resources/policies/health-care-reform/ [http:// perma.cc/BG4Y-B69Q] (last revised Mar. 6, 2015).

2 The Affordable Care Act and HIV/AIDS, supra note 1; Bolin, supra note 1; Alan I. Widess, HIV Infection Among Women of Reproductive Age, Children, and Adolescents: To Insure or Not to Insure Persons Infected with the Virus that Causes AIDS, 77 IowA L. REV. 1617, 1680 (1992).

3 The Affordable Care Act and HIV/AIDS, supra note 1.

4 Nat'l Fed'n of Indep. Bus. v. Sebelius, 132 S. Ct. 2566, 2580 (2012).

542 U.S.C. $\S 18031(\mathrm{~b})(1)(2015) ; 42$ U.S.C. $\S 18041(\mathrm{c})(1)(2015)$.

626 U.S.C. $\S 5000 A(2015)$.

726 U.S.C. $\S 36$ B (2015).

842 U.S.C. $\S \S 300 \mathrm{gg}-300 \mathrm{gg}-7$ (2015).

9 Id. 


\section{Health Insurance Exchanges}

The health insurance exchanges are online marketplaces that individuals can utilize to compare and purchase health insurance plans. ${ }^{10}$ The exchanges are meant to be a sort of one-stop shop for health insurance. ${ }^{11}$ The idea is that each State's exchange will provide people that are looking for health insurance with an opportunity to view and compare plans side-by-side; this format was designed to increase competition between health insurers and thus promote better and cheaper health plans. ${ }^{12}$ The ACA also uses the exchanges as a mechanism for regulation. Many of the ACA's regulations apply only to plans that are offered and obtained through the exchanges. ${ }^{13}$

\section{The Individual Mandate}

The individual mandate, put simply, requires Americans to purchase minimum essential coverage health insurance or else pay a tax penalty. ${ }^{14}$ However, the ACA's unaffordability exemption provides that if the cost of the cheapest plan on a State's exchange exceeds $8 \%$ of an individual's income, that person is not required to purchase health insurance and is also exempt from the tax penalty that would normally be assessed to persons who do not have health insurance. ${ }^{15}$

10 Health Insurance Marketplace, HEALTHCARE.GOV, https:// www.healthcare.gov/glossary/health-insurance-marketplace-glossary/ [http://perma.cc/F5NW-DWSA] (last visited Sept. 16, 2015).

${ }_{11}$ Creating a New Competitive Health Insurance Marketplace, CMS.GOV, http://www.cms.gov/CCIIO/Resources/Marketplace-Grants/ [http://perma.cc/34QW-5VYJ] (last visited Sept. 16, 2015).

12 Health Insurance Marketplace, supra note 10.

13 Bernadette Fernandez, Health Insurance Exchanges Under the Patient Protection and Affordable Care Act (ACA), CONGRESSIONAL RESEARCH SERVICE (Jan. 31, 2013), https://www.fas.org/sgp/crs/misc/ R42663.pdf [https://perma.cc/HKW5-3QMC].

1426 U.S.C. $\S 5000 \mathrm{~A}(2015)$.

1526 U.S.C. $\S 5000 \mathrm{~A}(\mathrm{e})(1)(\mathrm{A})$; Exemptions from the Fee for Not Having Health Insurance, HEALTHCARE.GOV, https:// www.healthcare.gov/fees-exemptions/exemptions-from-the-fee/ [http:// perma.cc/457Y-58T6] (last visited Sept. 16, 2015). 
There are also a number of other exemptions that allow individuals to not purchase health insurance and still avoid the tax penalty, most of which involve circumstances in which an individual is under financial stress. ${ }^{16}$ However, since the ACA expanded Medicaid to cover all individuals between the ages of 18 and 65 whose income does not exceed $138 \%$ of the Federal Poverty Level, many of the individuals that qualify for these exemptions that stem from a lowincome will still have access to health insurance.17

\section{Premium Tax Credits}

More relevant here are the premium tax credits that the ACA provides. These tax credits are provided to low- and middle-income Americans to subsidize the premiums of insurance they purchase through the exchanges. Because of this function, they are often referred to as premium subsidies. 18 Premium subsidies are available to individuals and families with an annual income of up to $400 \%$ of the Federal Poverty Level. ${ }^{19}$ These premium subsidies are paid by the Federal government directly to a qualifying individual's insurance provider in order to subsidize the qualifying individual's premiums under the plan. ${ }^{20}$

16 Exemptions from the Fee for Not Having Health Insurance, supra note 15 .

17 Medicaid Expansion \& What It Means for You, HealthCARE.GOV, https://www.healthcare.gov/medicaid-chip/medicaid-expansion-and-you/ [http://perma.cc/EQ68-UCJ7] (last visited Sept. 16, 2015).

1826 U.S.C. $\S 36$ B (2015); Premium Tax Credit, HealthCARE.Gov, https://www.healthcare.gov/glossary/premium-tax-credit/ [http:// perma.cc/6B9U-EPQ4] (last visited Sept. 16, 2014).

${ }^{19}$ Explaining Health Care Reform: Questions about Health Insurance Subsidies, KAISER FAMILY FOUND. (Oct. 27, 2014), http://kff.org/ healthreform/issue-brief/explaining-health-care-reform-questions-abouthealth/ [http://perma.cc/XM22-P7FK].

2042 U.S.C. $\S 18082$ (2015); Subsidies: Tax Credits for Eligible Consumers, ASSURANT HEALTH, http://www.assuranthealth.com/corp/ ah/HealthCareReform/Premium-Subsidy.htm [http://perma.cc/ D4FZTPLJ] (last visited Sept. 16, 2015); Premium Tax Credit, supra note 18. 


\section{The Guaranteed Issue Requirement}

Also very pertinent to this situation is the ACA's guaranteed issue requirement. This requirement means that health insurers may not deny any individual coverage because that person has a preexisting condition, ${ }^{21}$ such as HIV/AIDS. ${ }^{22}$

\section{The Community Rating Requirement}

The community rating requirement makes it illegal for health insurers to discriminate against individuals with a preexisting condition, ${ }^{23}$ such as HIV/AIDS, ${ }^{24}$ in terms of the price of coverage. This requirement means that health insurers cannot charge individuals with a preexisting condition a higher rate for coverage than individuals without a preexisting condition. ${ }^{25}$ However, there are a few exceptions. Health insurers can still charge higher rates to individuals based on age, tobacco use, and geography. ${ }^{26}$ This means that rates may be higher for individuals that are older, use tobacco, or live in a geographic region of the U.S. in which medical costs are higher than average. ${ }^{27}$

\section{B. The Post-ACA Landscape: Three Insurance Practices}

As has just been briefly explained, the ACA has many moving parts that together create an environment that is supposed to bring access to affordable, quality health insurance to everyone, regardless of their health status or history. The guaranteed issue and community rating

2142 U.S.C. $\S \S 300 g g-300 g g-7$ (2015).

22 Health Insurance Market Reforms: Rate Restrictions, KAISER FAMILY FOUND. (June 2012), http:// kaiserfamilyfoundation. files.wordpress.com/2013/01/8328.pdf [http://perma.cc/27GR-G2Z4]; The Affordable Care Act and HIV/AIDS, supra note 1.

2342 U.S.C. $\S \S 300 \mathrm{gg}-300 \mathrm{gg}-7$ (2015).

24 Health Insurance Market Reforms: Rate Restrictions, supra note 22 .

25 Id.

2642 U.S.C. $\$ \S 300 \mathrm{gg}(2015)$.

27 Health Insurance Market Reforms: Rate Restrictions, supra note 22. 
requirements are two of the most important of these moving parts. Together, they mean that health insurers can no longer refuse to cover individuals with HIV/AIDS ${ }^{28}$ or charge such individuals a higher rate for coverage than those without the disease. ${ }^{29}$

However, some insurers are finding more subtle ways to continue discriminating against individuals with HIV/AIDS in an attempt to discourage them from enrolling in their plans. ${ }^{30}$ Specifically, these insurers have continued to discriminate in three main ways. First, many insurers are discriminating via the design of their prescription drug formularies. ${ }^{31}$ These insurers design their formularies with

28 The Affordable Care Act and HIV/AIDS, supra note 1.

2942 U.S.C. $\$ \S 300 \mathrm{gg}, 300 \mathrm{gg}-2$ (2015).

30 Michelle Andrews, Some Plans Skew Drug Benefits to Drive Away Patient, Advocates Warn, KAISER FAMILY Found. (July 8, 2014), http://www.kaiserhealthnews.org/stories/2014/july/08/some-plans-skewdrug-benefits-to-drive-away-patients-advocates-warn.aspx [http://perma.cc/V2VU-VBLG].

31 Letter from Thomas D. Yates, Exec. Dir., AIDS Legal Council of Chi. \& John Peller, CEO, AIDS Found. of Chi., to Andrew Boron, Dir., Ill. Dep't of Ins., 13 (Apr. 1, 2014) (on file with AIDS Found. of Chi.), available at http://www.afc.01.thirdwaveweb.com/resources/legacy/images/2014/ ALCC_AFC_Jenner_letter_re_HIV_meds_marketplace_updated_Apr_1 2014.pdf [http://perma.cc/Q9XY-T6UX]; See Press Release, AIDS Found. of Chi., Cost of HIV Medications in the Illinois Health Insurance Marketplace, 1 (Mar. 13, 2014) (on file with AIDS Found. of Chi.), available at http://www.hivhealthreform.org/wp-content/uploads/2014/ 03/IL-HIV-Med-coverage-Marketplace-March-20-2.pdf [http://perma.cc/ 5W4T-EDZV]; Letter from Robert Greenwald, Dir., Harvard Law Sch. Ctr. for Health Law \& Policy Innovation, to Kathleen Sebelius, Sec'y of the Dep't of Health \& Human Serv. (Oct. 21, 2013) (on file with Harvard Law School Center for Health Law \& Policy Innovation) available at http://www.hivhealthreform.org/wp-content/uploads/2013/10/HHS-

letter-with-Insurer-letter-and-contacts-enclosed.pdf [https://perma.cc/ 84N4-RQGN]; Michelle Andrews, Complaint Says Insurance Plans Discriminate Against HIV Patients, NPR (July 8, 2014), http://www.npr.org/blogs/health/2014/07/08/329591574/complaint-saysinsurance-plans-discriminate-against-hiv-patients [http://perma.cc/ 8QBJ-4XDY]; Andrews, supra note 30; Fair Pricing Coal., Health Insurance Marketplace Plans and People Living with HIV and/or Viral Hepatitis: The Affordable Care Act Requires Fair Drug Pricing and Access, FPC, http://fairpricingcoalition.org/wp-content/ uploads/ 2014/02/FPC-QHP-Policy-Guide-Feb-2014-1.pdf [http://perma.cc/R89MMB68] (last visited Sept. 16, 2014). 
all or most of the effective HIV/AIDS medications on the highest tiers. ${ }^{32}$ These tiers are characterized by very high cost sharing and deductibles, thus, making the medications placed on these tiers virtually unaffordable. ${ }^{33}$ For brevity, I will often refer to this practice as "high tiering." Second, many insurers discriminate against individuals with HIV/AIDS, who take HIV/AIDS medications, by imposing step-therapy requirements. ${ }^{34}$ Step-therapy requirements force individuals to use less effective drugs in order to prove them to be ineffective before qualifying for the use of effective medications. ${ }^{35}$ And third, these insurers impose preauthorization requirements for HIV/AIDS medications. ${ }^{36}$ Pre-authorization requirements force individuals to obtain permission from their insurer before every refill of their medications. ${ }^{37}$ These three insurance practices undermine the broad goal of the ACA and its provisions, that prohibit

32 Yates, supra note 31, at 16; See AIDS Found. of Chi., supra note 31; Greenwald, supra note 31; Andrews, supra note 31; Andrews, supra note 30; Fair Pricing Coal., supra note 31.

33 Yates, supra note 31, at 16; See AIDS Found. of Chi., supra note 31; Andrews, supra note 30.

34 Yates, supra note 31, at 2; AIDS Found. of Chi., Illinois Governor's Office Warns ACA Health Insurance Plans Against HIV/AIDS Discrimination, [hereinafter Illinois Governor's Office] AIDSCHICAGO.oRG (May 27, 2014), http://www.aidschicago.org/illinois-news/891-illinoisgovernors-office-warns-aca-health-insurance-plans-against-hivaidsdiscrimination [http://perma.cc/L3GC-EBUR]; Letter from the Steering Comm. of the HIV Health Care Access Working Group, to the Office for Civil Rights, U.S. Dep’t of Health \& Human Servs. (Sept. 30, 2013) (on file with the Steering Comm. of the HIV Health Care Access Working Group), available at http://www.nastad.org/Docs/ 123257_ HHCAWG\%20Non\%20Disc\%20RFI\%20Response\%20FINAL.pdf.

[http://perma.cc/CX39-HEKS].

35 Yates, supra note 31, at 2; see also Illinois Governor's Office, supra note 34; Steering Comm. of the HIV Health Care Access Working Group, supra note 34.

36 Yates, supra note 31, at 2; see HIV Med. Ass'n. et. al, Doctors \& Advocates Demand Better Health Coverage for HIV \& Hepatitis, HIVANDHEPATITIS.COM (Feb. 7, 2014), http:// www.hivandhepatitis.com/ hiv-policy-advocacy/4514-medical-experts-and-advocates-urge-betterhealth-coverage-for-people-with-hiv-and-hepatitis [http://perma.cc/ 5EP7-CES4]; see also Illinois Governor's Office, supra note 34; Steering Comm.of the HIV Health Care Access Working Group, supra note 34.

37 Yates, supra note 31, at 2; see HIV Med. Ass'n. et. al, supra note 36; see also Illinois Governor's Office, supra note 34; Steering Comm. of the HIV Health Care Access Working Group, supra note 34. 
discrimination based on preexisting condition, by discriminating against individuals with HIV/AIDS, discouraging such individuals from enrolling in health plans, and making health insurance less accessible to them.

\section{Section 1557 of the ACA}

Fortunately, § 1557 of the ACA may be an effective weapon in combating these three discriminatory practices. Section 1557 is the ACA's broad nondiscrimination provision. In relevant part, it provides:

(a) In general. Except as otherwise provided for in this title (or an amendment made by this title), an individual shall not, on the ground prohibited under title VI of the Civil Rights Act of 1964 (42 U.S.C. 2000d et seq.), title IX of the Education Amendments of 1972 (20 U.S.C. 1681 et seq.), the Age Discrimination Act of 1975 (42 U.S.C. 6101 et seq.), or section 504 of the Rehabilitation Act of 1973 (29 U.S.C. 794), be excluded from participation in, be denied the benefits of, or be subjected to discrimination under, any health program or activity, any part of which is receiving Federal financial assistance, including credits, subsidies, or contracts of insurance, or under any program or activity that is administered by an Executive Agency or any entity established under this title (or amendments). The enforcement mechanisms provided for and available under such title VI, title IX, section 504, or such Age Discrimination Act shall apply for purposes of violations of this subsection. ${ }^{38}$

Most relevant here is that $\S 1557$ prohibits discrimination "on the ground ... prohibited under section 504 of the

38 Patient Protection and Affordable Care Act, Pub. L. No. 148, § 1557, 124 Stat. 119 (2010) (codified as amended at 42 U.S.C. $\S 18116$ (2010)). 
Rehabilitation Act of 1973,"39 which prohibits discrimination on the basis of disability. ${ }^{40}$ Since HIV/AIDS has been held by the Supreme Court-and other courts - to be a disability, ${ }^{41}$ $\S 1557$ through $\S 504$ of the Rehabilitation Act prohibits discrimination based on HIV/AIDS. However, the analysis of $\S 1557$ as applied to these three insurance practices does not end there.

\section{Roadmap}

This note seeks to determine whether $\S 1557$ will be effective at ending, or at least reducing, insurers' discrimination against individuals with HIV/AIDS in the form of high tiering, step-therapy and pre-authorization requirements. To make this determination, this note will adhere to the following itinerary. First, this note will explain in more detail the detrimental effects of the three aforementioned health insurance practices on individuals with HIV/AIDS in order to facilitate an understanding as to why they should be opposed. Next, it will examine what entities $\S 1557$ applies to. Then, this note will discuss whether $\S 1557$ prohibits intentional discrimination, and if so, whether these three insurance practices constitute such prohibited intentional discrimination. Next will be a discussion of whether $\S 1557$ prohibits disparate impact discrimination, and if so, whether such discrimination is present in this case. And finally, a policy consideration for the application of $\S 1557$ will be discussed.

\section{The Three Discriminatory Health INSURANCE PRACTICES}

Without an understanding of the nature of the HIV/AIDS virus and the standard of care for treating it, the harmful effects these three aforementioned insurance practices have

3942 U.S.C. $\S 18116$ (a) (2015).

4029 U.S.C. $\$ 794($ a) $(2015)$.

41 E.g., Bragdon v. Abbott, 524 U.S. 624, 630-47 (1998) (ADA); Doe v. Cnty. of Ct., PA, 242 F.3d 437, 447 (3d Cir. 2001) (Rehabilitation Act); Chalk v. U.S. Dist. Ct. C.D. Cal., 840 F.2d 701, 705-09 (9th Cir. 1988) (Rehabilitation Act). 
on individuals with HIV/AIDS cannot be fully appreciated. Therefore, a brief overview of HIV/AIDS is appropriate.

\section{A. The Nature and Standard of Care for Treating HIV/AIDS}

HIV/AIDS is an extremely complex virus that attacks the human immune system. ${ }^{42}$ HIV/AIDS can replicate billions of times per day and has a very error-prone replication process; as a result, it has an extremely high mutation rate. ${ }^{43}$ Because of this, treating HIV/AIDS is very difficult. In order to effectively manage the virus, multiple HIV/AIDS medications must be used in unison. ${ }^{44}$ Furthermore, any cessation in an individual taking medication gives the virus the opportunity to replicate, mutate, and become resistant to that medication. ${ }^{45}$ Drug resistant HIV/AIDS is extremely troubling because not all HIV/AIDS medications work for a particular individual, ${ }^{46}$ and many HIV/AIDS medications have toxic side effects. ${ }^{47}$ So if a person has a lapse in taking his or her effective medication, and their strain of HIV/AIDS becomes resistant to that medication as a result, that person cannot continue to take that drug and may have a limited selection of other

42 What is HIV/AIDS?, AIDS.GOV, http://www.aids.gov/hiv-aidsbasics/hiv-aids-101/what-is-hiv-aids/ [http://perma.cc/X42Q-9MKW] (last revised Apr. 29, 2014).

43 Primer on HIV Resistance, Stanford University HIV Drug RESISTANCE DATABASE, http://hivdb.stanford.edu/pages/documentPage/ primer.html [http://perma.cc/5R9U-DHAS] (last updated Sept. 23, 1999).

44 Panel on Antiretroviral Guidelines for Adults and Adolescents, GUIDELINES FOR THE USE OF ANTIRETROVIRAL AGENTS IN HIV-1-INFECTED ADULTS AND ADOLESCENTS, DEP'T OF Health \& HuM. SERVICES D-1, http://aidsinfo.nih.gov/contentfiles/lvguidelines/adultandadolescentgl.pd f [http://perma.cc/Z8X9-DH5B] (last visited Sept. 17, 2015).

45 Id. at $\mathrm{K}-1$.

46 Changing/Stopping Treatment, AIDS.GOV, https://www.aids.gov/ hiv-aids-basics/just-diagnosed-with-hiv-aids/treatment-options/ changing-stopping-treatment/ [http://perma.cc/QT4M-V39E] (last revised Aug. 7, 2009).

47 Yates, supra note 31, at 5; Antiretroviral Drugs Side Effects, AVERT, http://www.avert.org/antiretroviral-drugs-side-effects.htm [http://perma.cc/CRG3-D84A] (last visited Sept. 17, 2015). 
drugs to switch to due to side effects and ineffectiveness. Because of this, the medical standard of care for treating HIV/AIDS provides that a person diagnosed with HIV/AIDS begin taking medication as soon as possible after being diagnosed and have no lapses in treatment. 48 In order to facilitate this, the medical standard of care provides that the most effective way to treat HIV/AIDS patients is with a single-tablet regimen (STR) instead of multiple pills per day ${ }^{49}$ - this increases adherence to treatment, decreasing dangerous interruptions in treatment. ${ }^{50}$ The medically "preferred regimens" of STRs for treating HIV/AIDS include Atripla, Truvada-Reyataz-Norvir, Truvada-Prezista-Norvir, Truvada-Isentress, Stribild, Tivicay-Epzicom, and TivicayTruvada. ${ }^{51}$

With a better understanding of how HIV/AIDS works and is treated, a look into how high tiering, step-therapy, and preauthorization requirements can negatively affect individuals with HIV/AIDS is now appropriate.

\section{B. The Detrimental Effects of These Three Aforementioned Practices on Individuals with HIV/AIDS}

The next three subsections will explain how high tiering, step-therapy, and pre-authorization requirements can have harmful consequences for individuals with HIV/AIDS.

48 Panel on Antiretroviral Guidelines for Adults and Adolescents, supra note 44 , at $\mathrm{K}-1$.

49 Liz Highleyman, Single-Tablet Regimen Improves Antiretroviral Adherence and Reduces Hospitalization, AIDSMAP (Sept. 26, 2013), http://www.aidsmap.com/Single-tablet-regimen-improves-antiretroviraladherence-and-reduces-hospitalisation/page/2763722/ [http://perma.cc/ X8YW-95BP].

50 Yates, supra note 31, at 17.

51 AIDS Found. of Chi., supra note 31 , at 3-12. 


\section{High Tiering}

HIV/AIDS medications are very expensive. ${ }^{52}$ A 30-day supply of Norvir costs $\$ 530-\$ 58653$; a 30 -day supply of Prezista costs $\$ 1,279-\$ 1,38354$; a 30 -day supply of Reyataz costs $\$ 1,288-\$ 1,39355$; a 30 -day supply of Truvada costs $\$ 1,309-\$ 1,411^{56}$; and generic versions of these drugs are not available in the United States. ${ }^{57}$ But even drugs that do have generic alternatives available in the United States are expensive. ${ }^{58}$ For example, a 30-day supply of generic Combivir is $\$ 172-\$ 375$, and a 30 -day supply of generic Ziagen is $\$ 117-\$ 219.59$ And remember, it is necessary for an individual with HIV/AIDS to take not only one of these drugs, but a combination of these drugs in unison. 60 But, one might think, the above numbers are the total costs of the drugs; with insurance the drugs are probably cheap enough that people can afford them, right? Not when these drugs are placed on the highest cost sharing tiers of a health insurers' prescription drug formulary. ${ }^{61}$

In Illinois, Aetna, Coventry, and Humana all place most HIV/AIDS medications, and indeed all of the medically preferred regimens, on the highest tiers of their formularies. ${ }^{62}$ For example, under the best plan that Aetna

52 See Kimberly Holland \& Kristeen Cherney, The Cost of HIV Treatment, HeALTHLINe (April 2, 2015), http:// www.healthline.com/ health/hiv-aids/cost-of-treatment\#1 [http://perma.cc/2XEY-SSHL]; Madeline Vann, Can You Afford Your HIV Treatment?, EvERYDAY HEALTH, http://www.everydayhealth.com/hiv-aids/can-you-afford-hivtreatment.aspx [http://perma.cc/RZ8L-UBUF] (last updated May 13, 2009).

53 Holland, supra note 52.

54 Id.

$55 I d$.

56 Id.

57 Id.

$58 I d$.

59 Id.

60 Panel on Antiretroviral Guidelines for Adults and Adolescents, supra note 44.

61 Yates, supra note 31, at 16-17; See AIDS Found. of Chi., supra note 31; Andrews, supra note 30.

62 AIDS Found. of Chi., supra note 31. 
offers on the Illinois Health Insurance Exchange, the monthly out-of-pocket cost to a plan beneficiary for Atripla is about $\$ 1,126$; for Truvada-Reyataz-Norvir is about $\$ 1,541$; for Truvada-Prezista-Norvir is about $\$ 1,542$; for TruvadaIsentress is about $\$ 1,348$; for Stribild is about $\$ 2,830$; for Tivicay-Epzicom is about $\$ 654$; and for Tivicay-Truvada is about $\$ 783.63$

Under the best plan that Coventry offers on the Illinois Health Insurance Exchange, the monthly out-of-pocket cost to a plan beneficiary for Atripla is about $\$ 676$; for TruvadaReyataz-Norvir is about $\$ 763$; for Truvada-Prezista-Norvir is about $\$ 763$; for Truvada-Isentress is about $\$ 686$; for Stribild is about $\$ 843$; for Tivicay-Epzicom is about $\$ 703$; and for Tivicay-Truvada is about $\$ 792 .{ }^{64}$

And under the best plan that Humana offers on the Illinois Health Insurance Exchange, the monthly out-ofpocket cost to a plan beneficiary for Atripla is about $\$ 1,126$; for Truvada-Reyataz-Norvir is about $\$ 1,541$; for TruvadaPrezista-Norvir is about $\$ 1,542$; for Truvada-Isentress is about $\$ 1,348$; for Stribild is about $\$ 1,405$; for TivicayEpzicom is about $\$ 1,172$; and for Tivicay-Truvada is about $\$ 1,321.65$

In 2013, the median household, or combined family, income ranged from about $\$ 90,000$ to about $\$ 45,000$ per year. ${ }^{66}$ So if someone with a $\$ 60,000$ yearly salary were to have the best plan that Humana offers through the Illinois marketplace and that person had been prescribed Atripla, he or she would be spending over $22 \%$ of their yearly income on their Atripla alone. If someone with a $\$ 45,000$ yearly salary were to have the best plan that Humana offers through the Illinois marketplace and that person had been prescribed Atripla, he or she would be spending about $30 \%$ of their yearly income on their Atripla alone. Thirty percent of a family's income is a substantial amount, to say the least. Thus, it seems safe to say that when these drugs are placed

$63 I d$.

64 Id.

65 Id.

66 Amanda Noss, Household Income: 2013, American Community Survey Briefs, U.S. CENsus BuREAU (Sept. 2014), http:// www.census.gov/ content/dam/Census/library/publications/2014/acs/acsbr13-02.pdf [http:// perma.cc/KG7D-8898]. 
in an insurer's highest formulary tiers, they are extremely expensive and virtually unaffordable to most low- and middle-income Americans.

It is apparent that this practice of high tiering by insurers can be financially challenging, or even crippling-depending on an individual's income. This financial burden by itself imposes great harm to individuals with HIV/AIDS. However, the harm does not stop at the pocketbook. Such a high cost for these drugs can mean that many people with HIV/AIDS cannot afford their medication every month. What happens when someone cannot afford to pay for his or her medication for a month? Answer: they do not take it. This is a lapse in treatment, which can lead to a dangerous strain of drugresistant HIV/AIDS. 67

In sum, this high tiering practice may not only create an extreme financial burden on beneficiaries with HIV/AIDS, but can also lead to medically dangerous lapses in treatment.

\section{Step therapy requirements}

Step-therapy requirements force individuals to use less effective drugs in order to prove they are ineffective before qualifying for the use of effective medications. 68 The medical standard of care dictates that an individual should begin treatment as soon as possible after being diagnosed with HIV/AIDS and have no lapses in treatment.69 This keeps the virus at bay from mutation and thus prevents drug resistance. ${ }^{70}$ Step-therapy, by its very nature, violates this standard of care and gives the virus the opportunity to mutate and become drug resistant because either: (1) a person is diagnosed with HIV/AIDS and enrolls in a plan-or is already enrolled in a plan-with a step-therapy requirement that requires them to take less-than-optimallyeffective drugs for a period of time, which functionally

67 Yates, supra note 31, at 4.

68 Yates, supra note 31, at 2; see Illinois Governor's Office, supra note 34; Steering Comm. of the HIV Health Care Access Working Group, supra note 34 .

69 Panel on Antiretroviral Guidelines for Adults and Adolescents, supra note 44.

70 See id. 
constitutes a delay in initial treatment; or (2) a person who has had HIV/AIDS for some time and has been using an effective drug enrolls in a plan that has a step-therapy requirement and must switch to a less effective drug for a period of time, which functionally constitutes a lapse in treatment. It is in this way that step-therapy requirements harm individuals with HIV/AIDS who are subjected to them.

\section{Pre-authorization requirements}

Pre-authorization requirements have largely the same effect that step-therapy requirements do: they cause lapses in treatment. This is because pre-authorization requirements mandate that beneficiaries must obtain permission from the insurer before every refill of their medication, ${ }^{71}$ and due to the large size and bureaucratic nature of insurance companies, that permission can often take longer to obtain than expected. ${ }^{72}$ This delay in permission from the insurance companies can lead to dangerous lapses of treatment. It is in this way that preauthorization requirements harm individuals with HIV/AIDS who are subjected to them.

It is apparent that these three health insurance practices are acutely detrimental to individuals with HIV/AIDS who are subject to them. However, § 1557 may be able to neutralize these practices and provide such individuals with relief from this discrimination. An analysis of $\S 1557$ and its possible application to such practices follows.

\section{COVERED ENTITIES UNDER § 1557}

To determine whether $\S 1557$ of the ACA will be effective at ending, or at least reducing, insurers' practices of high tiering and step-therapy and pre-authorization requirements with HIV/AIDS medications, it is necessary to determine what entities the provision actually applies to. To be an effective means of combating these health insurance practices, $\S 1557$ must extend to the vast majority of health

71 Yates, supra note 31, at 15; see HIV Med. Ass'n. et. al, supra note 36; see Illinois Govenor's Office, supra note 34.

72 Yates, supra note 31, at 15. 
insurance companies and thus by extension to the health plans they provide.

Section 1557 applies to "any health program or activity, any part of which is receiving Federal financial assistance, including credits, subsidies, or contracts of insurance, or under any program or activity that is administered by an Executive Agency or any entity established under this title (or amendments)."73 There are two key pieces at work here: "health program or activity" and "Federal financial assistance." Therefore, to determine whether $§ 1557$ extends to health insurance companies, these two key pieces must be examined. First, it must be determined what "Federal financial assistance" is and whether health insurance companies receive it. And second, it must be determined what a health "program or activity" is and if health insurance companies qualify as such a health "program or activity." If health insurance companies do qualify as health "programs or activities" and receive "Federal financial assistance," section 1557 will apply to such health insurers.

\section{A. "Federal Financial Assistance"}

What qualifies as "Federal financial assistance?" There is a vast array of Federal programs that provide various types of assistance. However, the ACA's premium tax credits will be focused on here. This is partly due to the impracticability of exploring every Federal program that provides financial assistance and partly due to the importance and prominence of the premium tax credits. The premium tax credits are especially pertinent in the context of $\S 1557$ covered entities because many people will qualify for them. ${ }^{74}$ So if these credits qualify as "Federal financial assistance" then many insurers will receive such federal assistance because they provide coverage to those individuals who qualify for the credits.

7342 U.S.C. $\S 18116$ (a) (2015).

74 State-by-State Estimates of the Number of People Eligible for Premium Tax Credits Under the Affordable Care Act, KAISER FAMILY Foundation (Nov. 5, 2013), http://kff.org/report-section/state-by-stateestimates-of-the-number-of-people-eligible-for-premium-tax-creditsunder-the-affordable-care-act-table-1/ [http://perma.cc/X3FM-QZTC]. 
Section 1557 explicitly provides that "Federal financial assistance" includes "credits, subsidies, or contracts of insurance." 75 The "credits" and "subsidies" referred to by $\S$ 1557 seemingly refer to-or at least include-the premium tax credits provided pursuant to the ACA. This makes sense for two reasons. First, it is logical for $\S 1557$ to refer to and use such a key piece of the Act of which it is a part of to effect its specific purpose. As was explained above, the premium tax credits are a key part of the ACA. Without the premium tax credits, the ACA could not stand. ${ }^{76}$ It makes sense for the ACA to use such a key component of itself to be the foundation of this nondiscrimination provision. And second, the premium tax credits are both a "credit"-in that they are literally a tax credit—and a "subsidy" - in that they literally subsidize insurance premiums. Furthermore, the premium tax credits are the epitome of "Federal financial assistance;" the federal government is literally assisting in the payment of insurance premiums.

As the analysis above illustrates that it is likely that premium tax subsidies qualify as "Federal financial assistance," the next inquiry to make here is: will most health insurance companies receive these premium tax subsidies? More and more health insurance companies offer, or will offer, health plans through the exchanges. ${ }^{77}$ Thus, it is very likely that each insurer offering plans through the exchanges will inevitably receive premium subsidies through beneficiaries of some of those plans. This is because the premium subsidies are available for individuals and families with incomes up to $400 \%$ of the federal poverty level, which encompasses an extremely large group of people. ${ }^{78}$ With a

7542 U.S.C. § 18116(a) (2015).

76 Joel E. Miller, Healthcare Reform: The "Three-Legged Stool" of Health Insurance Reform Under the ACA, AMHCA (Oct. 1, 2013), http://www.amhca.org/?page=Advocate20131002 [http://perma.cc/8FA5M9BV].

77 Tami Luhby, More Health Insurers Offer Obamacare Plans, CNN Money (Sept. 23, 2014 3:58 PM), http://money.cnn.com/2014/09/23/ news/economy/obamacare-more-health-insurers-on-exchanges/ [http:// perma.cc/KD7F-TFFD].

78 Explaining Health Care Reform: Questions About Health Insurance Subsidies, KAISER FAMILY FOUNDATION (Oct. 27, 2014), http://kff.org/health-reform/issue-brief/explaining-health-care-reform- 
large, and increasing, number of health insurers offering plans on the exchanges and with a large portion of the population qualifying for premium subsidies, the vast majority of health insurers are likely to receive premium subsidies-"Federal financial assistance"-via the beneficiaries of their plans that are sold on the exchanges.

However, at first blush, there seems to be a wrinkle here. While the premium subsidy is paid directly to the insurer ${ }^{79}$ in actuality it is a premium tax credit of the individual who purchases the plan, and it subsidizes the cost of insurance to the individual. Therefore, one might think, the individuals, not the insurers, are receiving the "Federal financial assistance." However, this argument is not consistent with the law.

In Moreno v. Consolidated Rail Corp., Moreno, a terminated employee of the railroad company Conrail, filed suit under $\S 504$ of the Rehabilitation Act alleging that his termination was due to his disability-diabetes. ${ }^{80}$ In response, Conrail maintained that it was not a recipient of federal financial assistance and therefore not subject to $§ 504$ regulation. ${ }^{81}$ Conrail received government money for railroad crossing improvements. ${ }^{82}$ The improvements were paid to the State of Michigan and then subsequently to Conrail. ${ }^{83}$ Conrail argued that while it did receive such government money, it was not the "recipient" of federal financial assistance because the ultimate beneficiary was the traveling public, who benefitted from safe railroad crossings. ${ }^{84}$ The court found this argument unpersuasive,

questions-about-health/ [http://perma.cc/EW37-6632]; State-by-State Estimates of the Number of People Eligible for Premium Tax Credits Under the Affordable Care Act, supra note 74.

7942 U.S.C. § 18082 (2015); Subsidies: Available to Eligible Consumers, ASSURANT HEALTH, http://www.assuranthealth.com/corp/ ah/HealthCareReform/Premium-Subsidy.htm [http://perma.cc/CZL57RRC] (last visited Sept. 17, 2015); Premium Tax Credit, HEALTHCARE.GOV, https://www.healthcare.gov/glossary/premium-taxcredit/ [http://perma.cc/5YT4-PMK3] (last visited Sept. 17, 2015).

80 Moreno v. Consol. Rail Corp., 99 F.3d 782, 784 (6th Cir. 1996).

$81 \mathrm{Id}$.

82 Id. at $785-786$.

$83 \mathrm{Id}$.

84 Id. at 787. 
and further found the fact that Conrail received the money from the Federal government through the State of Michigan as a middle-man to be immaterial. ${ }^{85}$ The Court held Conrail to be a recipient of "Federal financial assistance." 86

Similarly, the Supreme Court, in Grove City College v. Bell, spoke on the scope of the coverage of antidiscrimination statutes. ${ }^{87}$ In Grove City College, a college refused to agree to the antidiscrimination terms under Title IX of the Education Amendments of 1972 in order to utilize certain student educational funding. ${ }^{88}$ The Court found that although the students were the ultimate beneficiaries of the student educational funding, the college was a "recipient" of federal financial assistance due to such government funding. 89

In addition, the Department of Health and Human Services ("HHS") has issued a regulation which defines a "recipient" under $\S 504$ as "any state . . or any person to which Federal financial assistance is extended directly or through another recipient ... but excluding the ultimate beneficiary of the assistance." 90

In the current situation, the ultimate beneficiary of the premium subsidies are the individuals who qualify for such premium tax credits. However, the premium subsidies are paid from the Federal government directly to the health insurer. ${ }^{91}$ Indeed, this is more direct than in Moreno when the State of Michigan acted as a middle-man and the court in that case still found Conrail to be a recipient of "Federal financial assistance." In addition, the health insurers in the current situation are like Conrail in Moreno and the college in Grove City College: although they are not the true beneficiaries of the federal funds, they still qualify as recipients of "Federal financial assistance." Indeed, individuals who qualify for premium tax credits are equivalent to the students in Grove City College who

85 Moreno v. Consolidated Rail Corp., 99 F.3d at 787-788.

86 Id.

87 Grove City College v. Bell, 465 U.S. 555 (1984).

88 Id. at 561.

89 Id. at $569-570$.

9045 C.F.R. $\S 84.3(f)(2015)$.

9142 U.S.C. § 18082 (2015); Subsidies: Tax Credits for Eligible Consumers, supra note 79; Premium Tax Credit, supra note 79. 
qualified for student educational funding. They are the ultimate beneficiaries of the funding, but because the money is paid to the institution handling their affairs, the institution is the recipient of "Federal financial assistance" for legal purposes.

Moreover, the HHS regulations have specifically excluded ultimate beneficiaries, such as the students in Grove City College or the plan beneficiaries who qualify for premium tax credits in the current situation, from being the legal recipients of "Federal financial assistance" and instead designated the entity that the government money is extended to as the recipient.

Therefore, health insurance companies become the recipients of "Federal financial assistance" when they receive government money in the form of premium tax subsidies. This greatly expands the coverage of $\S 1557$. Also keep in mind that there are many other ways that an insurer can receive "Federal financial assistance" aside from premium tax subsidies. Taking that into consideration, § 1557's coverage is broader still. Therefore, most insurance companies in the United States will likely receive "Federal financial assistance."

\section{B. "Program or Activity"}

Since, in this context, discrimination against individuals with HIV/AIDS is prohibited by $\S 1557$ through its invocation of $\S 504$ of the Rehabilitation Act, and because $\S 1557$ does not specifically define "program or activity," it seems appropriate to use the definition of "program or activity" provided by $\S 504$ of the Rehabilitation Act. Section 504 of the Rehabilitation Act provides that, among other things, a "program or activity" means all operations of: (3)(A) an entire corporation, partnership, or other private organization, or an entire sole proprietorship-(i) if assistance is extended to such corporation, partnership, private organization, or sole proprietorship as a whole; or (ii) which is principally engaged in the business of providing education, health care, housing, social services, or parks and recreation[.] ${ }^{92}$

9229 U.S.C. $§ 794(b)$ (2015). 
With this definition, it is now possible to answer the question: do health insurance companies qualify as health "programs or activities?" Insurance companies are corporations. However, there are a great many insurance companies in the United States and not all of their corporate structures are the same. This makes a broad analysis of whether health insurers receive assistance "as a whole" overly cumbersome. This point is also moot due to the second portion of the definition of "program or activity" presented above.

This is because even if a health insurer does not receive the assistance "as a whole," they still qualify as a "health program or activity." The second piece of the definition of health "program or activity" only requires that the corporation be "principally engaged in the business of providing . . . health care." Since insurance companies are "principally engaged in the business of providing" health care, they likely qualify as a "program[] or activit[y]."

\section{Putting It Together}

Having explored the two key pieces of $\S 1557$ that describe covered entities, it is now appropriate to put those two key pieces together in regard to health insurance companiesand by extension the health plans such insurers provide. Health insurance companies likely qualify as health "programs or activities"; and they will probably receive "federal financial assistance" in one form or another; therefore, they are likely covered entities under $\S 1557$. However, the covered entity analysis does not stop here; there is one important question that must still be answered.

\section{A Wrinkle?}

If a health insurance company receives federal financial assistance in the form of the ACA's premium subsidies from one plan offered through an exchange, does that company have to make sure that all of the plans it offers, both in and out of the exchanges, comply with $\S 1557$ ? 
The Supreme Court, in Grove City College v. Bell, spoke on the scope of the coverage of antidiscrimination statutes. ${ }^{93}$ Recall that Grove City College was the case in which a college did not want to comply with antidiscrimination regulations in order to be able to utilize federal funds for its students. ${ }^{94}$ The Court found that the Department of Education had the authority to withdraw the student educational funding because Grove City College received federal financial assistance through that student funding. ${ }^{95}$ However, the Court noted that only the specific funding program that received the Federal financial assistance was subject to regulation and not Grove City College as a whole. ${ }^{96}$ Essentially, the court took a very narrow approach to "program or activity." Under this approach, if an institution were to receive "Federal financial assistance," only the specific part of the institution that received that assistance would be subject to antidiscrimination regulations, not the institution as a whole in every aspect of its business.

But this narrow reading by the Court does not negatively affect the current situation being analyzed. Here, a health insurance company receives federal financial assistance through premium subsidies. According to Grove City College, the antidiscrimination scrutiny must be "program specific." 97 However, this does not mean scrutiny is extended only to the plan which triggered the premium subsidy but rather that scrutiny is extended to the entire program of the health insurance company which provides health plans. This is so because no case law has taken "program specific" to the extreme of meaning "individually specific." For example, in U.S. v. Baylor University Medical Center, the court sought to determine whether and to what extent Medicare and Medicaid payments subjected a hospital to the scrutiny of $\S$ 504 of the Rehabilitation Act. 98 The court first determined that Medicare and Medicaid payments qualified as "Federal

93 Grove City College v. Bell, 465 U.S. 555 (1984).

94 Id. at 561.

95 Id. at 575-576.

96 Id. at $570-571$.

97 Id.

98 U.S. v. Baylor University Medical Center, 736 F.2d 1039, 1040 (1984). 
financial assistance." 99 Then the Court sought to determine whether the antidiscrimination scrutiny applied to the hospital as a whole or to just the inpatient emergency room services that led to the Medicare and Medicaid payments in the first place. ${ }^{100}$ The Court held that the hospital's inpatient and emergency room services were subject to antidiscrimination scrutiny, but that the entire hospital as a whole was not because of the "program specific" requirement. ${ }^{101}$ Notice that the court did not say that only the specific individuals who caused the Medicare and Medicaid payments to be made to the hospital were subject to scrutiny, but rather all inpatient and emergency room services. In the current situation, it would not just be the specific, individual plan that will be subject to $\S 504-$ and thus $\S 1557$ - scrutiny, but rather the entire program that deals with insurance plans. So while only some plans will trigger the premium subsidies that make the insurance companies recipients of federal financial assistance, all plans which said company provides will likely be subject to 1557 .

\section{E. Other Means of $\mathcal{S} 1557$ Coverage}

While the premium tax credits system will likely serve as the broadest means by which a health insurance company can be subject to $\S 1557$ regulation, there are other means. First, Executive Agencies and any other entities established under the ACA are subject to $\S 1557$ regulation. 102 Second, Medicare and Medicaid payments will also trigger $\S 1557$ regulation. ${ }^{103}$ And lastly, health insurance companies that do not offer plans through the exchanges can receive "federal financial assistance" in a variety of other ways outside of premium tax subsidy payments, thus making them subject to $\S 1557$ regulation. With all of these various means by which health insurance companies can qualify as covered entities under $\S 1557$, the vast majority of health insurance plans in the United States should be subject to $§ 1557$.

99 Id. at $1048-1049$.

100 Id. at 1049.

101 Id.

10242 U.S.C. § 18116(a) (2015).

103 U.S. v. Baylor University Medical Center, 736 F.2d 1039, 10481049 (1984). 


\section{HIGH TIERING AND STEP-THERAPY AND PRE- AUTHORIZATION REQUIREMENTS: DISCRIMINATORY AND PROHIBITED UNDER $§ 1557 ?$}

In order to determine whether $\S 1557$ will be effective at ending health insurers' practices of high tiering and steptherapy and pre-authorization requirements for individuals with HIV/AIDS, it must be determined both what type and what mode of discrimination $\S 1557$ prohibits. The "type" of discrimination will refer to what basis discrimination is prohibited on. The "mode" of discrimination will refer to the method of discrimination: either intentional or disparate impact. 104 Then it must be determined whether high tiering and step-therapy and pre-authorization requirements constitute such prohibited discrimination under $\S 1557$.

Since $\S 504$ of the Rehabilitation Act is the relevant antidiscrimination statute invoked by $\S 1557$ in terms of HIV/AIDS discrimination, this discussion will be based on $\S$ 504.

\section{A. What Type of Discrimination is Prohibited by $\S 1557$ ?}

Section 1557 prohibits discrimination "on the ground prohibited under . . . section 504 of the Rehabilitation Act."105 Section 504 of the Rehabilitation Act prohibits discrimination on the basis of disability. ${ }^{106}$ The Supreme Court has held HIV/AIDS to be a disability. ${ }^{107}$ Therefore, $\S$ 1557 prohibits discrimination on the basis of HIV/AIDS status. But presently, the aforementioned insurance practices are not explicitly based on the forbidden criterion HIV/AIDS. While disability is a forbidden criterion on which

104 Disparate impact discrimination occurs when "practices that are facially neutral in their treatment of different groups . . . in fact fall more harshly on one group than another." Smith v. City of Jackson, 544 U.S. 228, 239 (2005).

10542 U.S.C. $\S 18116(\mathrm{a})(2015)$.

10629 U.S.C. $\S 794(\mathrm{a})$ (1973).

107 E.g., Bragdon v. Abbott, 524 U.S. 625, 630-647 (1998) (ADA); Doe v. County of Centre, Pa., 242 F.3d 437, 447 (3d Cir. 2001) (Rehabilitation Act); Chalk v. United States Dist. Ct., 840 F.2d 701, 704-709 (9th Cir. 1988) (Rehabilitation Act). 
to discriminate and HIV/AIDS is a disability, high tiering and step-therapy and pre-authorization requirements do not technically apply directly to individuals with HIV/AIDS but rather apply to the HIV/AIDS drugs themselves. So the question becomes: is discrimination targeted at HIV/AIDS medications the same as discrimination against individuals with HIV/AIDS?

In Lawrence v. Texas, the Supreme Court held that a same-sex sodomy law discriminated against homosexuals because it targeted conduct that was closely tied with being homosexual. 108 The Court concluded "there can hardly be more palpable discrimination against a class than [targeting] the conduct that defines that class." 109 Here, insurance companies have not targeted conduct that technically defines the class, individuals with the disability of HIV/AIDS; however, the insurance companies have targeted conduct that is closely tied to the class. Indeed, the taking of HIV/AIDS medications is absolutely necessary for someone with the disease in order to stay alive. However, same-sex sodomy is not absolutely necessary for homosexual individuals to stay alive. So, same-sex sodomy is actually less linked with being a homosexual than taking HIV/AIDS medications is with being an individual with HIV/AIDS. Therefore, targeting HIV/AIDS medications seems equivalent to targeting individuals with HIV/AIDS.

In sum, § 1557 prohibits discrimination based on HIV/AIDS status, and that prohibition extends to discrimination based on HIV/AIDS medications because of the extremely close link between having HIV/AIDS and the necessity for taking HIV/AIDS drugs.

\section{B. Intentional Discrimination: Prohibited?}

In order to determine whether the three aforementioned insurance practices are prohibited by $\S 1557$ as intentional discrimination, it must first be determined whether $\S 1557$ actually prohibits intentional discrimination. The Supreme Court has spoken as to what discrimination qualifies as a

108 See Lawrence v. Texas, 539 U.S. 558, 583 (2003).
109 Id. 
violation of $\S 504$ of the Rehabilitation Act. Indeed, in Alexander v. Choate, the Supreme Court interpreted § 504 of the Rehabilitation Act. ${ }^{110}$ The Court was not even concerned as to whether $\S 504$ prohibits intentional discrimination; it took that for granted.111 The Court used intentional discrimination as a starting point, or a floor, for $\S 504 .{ }^{112}$ The issue, in the Court's opinion, was not whether $\S 504$ prohibits intentional discrimination but whether it prohibits disparate impact discrimination. ${ }^{113}$ From Alexander v. Choate, it is clear that $\S 504$ prohibits intentional discrimination. Indeed, if it did not, the provision would be meaningless. Intentional discrimination is the most blatant and most basic form of discrimination. If intentional discrimination is not prohibited by $\S 504$, then no discrimination is prohibited and the law is useless.

\section{High Tiering and Step-Therapy and Pre-Authorization Requirements: Intentional Discrimination?}

\section{Preliminary Question 1: Are These Three Insurance Practices Discriminatory to Begin With?}

Discrimination is not defined in $\S 1557$. However, courts have traditionally found "discrimination" to mean differential treatment based on a forbidden criterion. ${ }^{114}$ Since it is apparent that individuals with HIV/AIDS - which is a disability and therefore a forbidden criterion - are being targeted by these practices, it must be determined whether these practices constitute differential treatment. High tiering, step-therapy and pre-authorization requirements seem to constitute differential treatment. These practices deny meaningful coverage to individuals with HIV/AIDS and do not occur with other individuals.

When an insurer places all or most of the effective HIV/AIDS drugs on the highest cost-sharing tiers of their

110 Alexander v. Choate, 469 U.S. 287 (1985).

111 Id. at 292.

112 Id.

113 Id. at $292-293$.

114 See Jackson v. Birmingham Bd. of Educ., 544 U.S. 167, 174 (2005); Rene v. MGM Grand Hotel, Inc., 305 F.3d 1061, 1067 (9th Cir. 2002). 
prescription drug formularies, it makes those drugs virtually unaffordable. ${ }^{115}$ This leaves individuals with HIV/AIDS only able to afford either ineffective or toxic generic HIV/AIDS medications. If an individual with HIV/AIDS does still try to go the route of taking the overly expensive HIV/AIDS on the high tiers, they often cannot afford those medications on a monthly basis, causing the extremely dangerous interruptions in treatment the medical standard of care seeks to avoid.116 Step-therapy and pre-authorization requirements only add to the likelihood of treatment interruption. Step-therapy requirements require individuals to take less effective and potentially toxic generic drugs before moving on to the brand-name drugs that are actually effective. 117 Individuals with HIV/AIDS subjected to steptherapy requirements are really experiencing an interruption in treatment since their HIV/AIDS is not being effectively treated but allowed to replicate and mutate.

Finally, pre-authorization requirements also cause interruptions in treatment. Since an individual subjected to a pre-authorization requirement must obtain permission from his or her insurer before every refill of their medication, there are often delays in obtaining the refill for the medication, leading to dangerous interruptions in treatment. These insurance practices cause effective HIV/AIDS drugs to be virtually unaffordable and cause dangerous interruptions in treatment. Therefore, these insurance practices cause the plans to be effectively useless to individuals with HIV/AIDS, as opposed to individuals without the disease. Since individuals without HIV/AIDS do not need HIV/AIDS medications, these plans would be more favorable for individuals without the disease. This has the effect of discouraging individuals with HIV/AIDS from enrolling in these plans; but since individuals without HIV/AIDS do not require HIV/AIDS medication, these practices have no discouraging effect on individuals without HIV/AIDS. This is the differential treatment constituting discrimination.

115 Yates, supra note 31, at 16; AIDS Found. of Chi., supra note 31; Andrews, supra note 31.

116 Yates, supra note 31, at 15.

117 Yates, supra note 31, at 2; see AIDS Found. of Chi. supra note 31; HIV Health Care Access Working Group, supra note 34. 
2. Preliminary Question 2: Do Insurance Companies Have Autonomy in Choosing to Adhere to These Practices?

Before moving on to inquire as to whether the discrimination was intentional, another important point must be made. It seems obvious that that portion of insurers that adhere to the aforementioned practices do so intentionally. There is no law requiring these practices, and the practices were not written into the plan by accident. Each company designs its own prescription drug formularies and decides whether to institute step-therapy and preauthorization requirements for HIV/AIDS drugs. When an insurer places all or most effective HIV/AIDS drugs on the highest tiers of a prescription formulary and institutes steptherapy and pre-authorization requirements, it does so intentionally and not by market force. Note that it is not being said that these practices are intentionally discriminatory, but merely that they are intentionally put into place. Basically, insurance companies cannot say that they have no other choice than to implement these practices; they cannot say that there is no discriminatory intent because they simply did not want to implement these practices in the first place. If they did not want to or intend to implement these practices, they simply would not have done so.

\section{Are Health Insurance Companies that are Adhering}

to These Practices Exhibiting Intentional

Discrimination?

One can see that these insurance practices are discriminatory and that they are being implemented intentionally, but the big question here is whether this discrimination is intentional. How does one define intentional discrimination? In Lovell v. Chandler, a group of disabled individuals brought a class action under $\S 504$ of the Rehabilitation Act against the State of Hawaii alleging that they had been declared ineligible for Hawaii's "QUEST" 
medical coverage solely based on their disabilities. ${ }^{118}$ In 1994, Hawaii developed this "QUEST" program in order to provide health insurance to more of its low-income citizens. ${ }^{119}$ Hawaii explicitly and categorically excluded individuals who were over 65 years old, blind, or disabled. 120

For an award of compensatory damages, the Court needed to determine whether the state of Hawaii had intentionally discriminated against plaintiffs. ${ }^{121}$ The Court stated that an entity exhibits discriminatory intent - intentional discrimination - when it is "deliberate[ly] indifferen[t]."122 The Court went on to say that "[d]eliberate indifference requires both knowledge that a harm to a federally protected right is substantially likely, and a failure to act upon that likelihood."123 It continued, "The first element is satisfied when the . . . entity has notice that an accommodation is required. The second element is satisfied if the entity's 'failure to act [is] a result of conduct that is more than negligent, and involves an element of deliberateness." 124 Furthermore, an entity "at the very least" exhibits "deliberate indifference" when facial discrimination is present because "by its very terms, facial discrimination is "intentional."'125

The Court reasoned that because Hawaii had categorically excluded disabled individuals from the program when it knew that doing so would mean some of those individuals would ultimately go without coverage altogether, it did not act with enough care to protect the rights of its disabled citizens. ${ }^{126}$ It also stated that Hawaii had facially discriminated against disabled individuals in the QUEST program. ${ }^{127}$ For these reasons, the Court found that Hawaii

118 Lovell v. Chandler, 303 F.3d 1039, 1044 (9th Cir. 2002), cert denied, 537 U.S. 1105 (2003).

119 Id. at 1045.

120 Id.

121 Id. at 1056.

122 Id.

123 Id. (quoting Duvall v. Cnty. of Kitsap, 260 F.3d 1124, 1139 (9th Cir. 2001).

124 Id.

125 Id. at 1057.

126 Id.

127 Id. 
had exhibited "deliberate indifference" and therefore intentional discrimination in the design of its QUEST program. ${ }^{128}$

It appears that the insurance companies that adhere to these practices are exhibiting "deliberate indifference" and are therefore intentionally discriminating. As described above, when discrimination is of the type described as facial discrimination, it is per se deemed to be intentional discrimination. It seems that is the type of discrimination at play here. It is not the case that there is some other criteria that is being used and these drugs are disproportionately affected by it. The companies that adhere to these practices are explicitly designating HIV/AIDS medications for high tiering and step-therapy and pre-authorization requirements. Therefore, this discrimination seems facial and thus intentional.

On the other hand, this discrimination might be viewed as not being facial simply because it does target the HIV/AIDS drugs and not individuals with HIV/AIDS themselves. However, as was previously explained, targeting HIV/AIDS drugs is the equivalent of targeting individuals with HIV/AIDS themselves. So the argument in favor of these practices constituting facial discrimination - and thus intentional discrimination-seems to remain strong. Indeed, the present situation is much like that in Lovell. Just as Hawaii had explicitly and categorically provided in its laws that the QUEST program excluded disabled individuals, some insurance companies are explicitly providing that these overly burdensome practices only apply to HIV/AIDS medications-thus effectively only to individuals with HIV/AIDS.

If these practices are not considered to be intentional discrimination under this sort of per se facial discrimination standard, they likely will be under the two-pronged "deliberate indifference" test laid out by the court in Lovell. Recall that "[t]he first element [of deliberate indifference] is satisfied when the . . . entity has notice that an accommodation is required. ${ }^{129}$ Here, all insurance companies

$128 \mathrm{Id}$.

129 Id. at 1056. 
are undoubtedly aware of the ACA's requirements. Therefore, all insurance companies know that the ACA makes an accommodation for individuals with a preexisting condition-here, HIV/AIDS-such that they may not be denied coverage or charged higher rates for such coverage than individuals without the preexisting condition. ${ }^{130}$ All insurance companies in the United States are aware of this ACA requirement. Actually, the mere fact that they are allowing individuals with HIV/AIDS to enroll in their plans and are not charging them higher baseline rates than individuals without a preexisting condition proves they are aware of the accommodation required by the ACA. Before the ACA, insurers would not have let individuals with HIV/AIDS enroll on their plans. If they did, they would charge them grossly higher baselines rates. These companies must be aware that an accommodation is required. Another similarity to Lovell arises here. Insurance companies are effectively denying individuals with HIV/AIDS coverage. In Lovell, the Court stated that the fact that Hawaii had discriminated against disabled individuals meant it was charged with notice that federal protection may apply and an accommodation required. ${ }^{131}$ Here, since insurance companies are discriminating against disabled individuals, they are on notice that an accommodation may be required.

Moving on, recall that "[t]he second element [of deliberate indifference] is satisfied if the entity's 'failure to act [is] a result of conduct that is more than negligent, and involves an element of deliberateness." 132 Here, the insurance companies adhering to these practices did not fail to act; rather, they acted affirmatively to deny individuals with HIV/AIDS the required accommodation. If a "failure to act" beyond that which is negligent constitutes deliberateness, an affirmative action surely qualifies. Here, one might think that these insurance companies are actually complying with the ACA's required accommodation because said companies are allowing individuals with HIV/AIDS to enroll in their plans and are not charging them higher baseline premiums.

13042 U.S.C. $\S 300 \mathrm{gg}-4$ (2015).

131 Lovell v. Chandler, 303 F.3d at 1057 (emphasis added).

132 Id. at 1056, (quoting Duvall v. County of Kitsap, 260 F.3d 1124 (9th Cir.2001)). 
This would be true if the insurers had not gone a step further and implemented these three practices. However, high tiering, step-therapy, and pre-authorization requirements effectively deny enrollment, or, at the very least, deny equivalent cost for the plans to individuals with HIV/AIDS. It is not just the case that these insurance companies' failure to act caused the denial of the required accommodation; it is the case that their affirmative action caused such a denial. Both prongs of the "deliberate indifference" test being fulfilled, and "deliberate indifference" constituting intentional discrimination, insurance companies that adhere to these three practices seem to be exhibiting intentional discrimination as prohibited under $\S 504$ of the Rehabilitation Act - and thus $\S 1557$ of the ACA.

That the health insurance companies adhering to these practices are exhibiting intentional discrimination makes sense intuitively as well. For insurance companies to be most profitable, they seek to insure as many low-risk, low-payout people as possible. However, the ACA, via the guaranteed issue and community rating requirements, keeps insurers from explicitly discriminating against individuals with HIV/AIDS in order to keep their groups low-risk, low-payout. Nonetheless, insurers still have motive to keep their groups low-risk and low-payout. Since HIV/AIDS patients are highrisk and high-payout, insurers want to insure as few of these individuals as possible. With this motive in mind, and such prohibitive and restrictive practices instituted by insurance companies against individuals with HIV/AIDS, the discrimination seems likely to be intentional. What other reason would insurance companies have to institute these practices? It is obvious that these practices go against the medical standard of care for treating HIV/AIDS.

Furthermore, step-therapy and pre-authorization requirements are not always cost-saving methods for insurance companies. This is because of their aptitude to cause interruptions or delays in treatment. These lapses in treatment allow the virus to grow, mutate, and continue to attack the immune system. ${ }^{133}$ When this happens, the human immune system is obviously severely weakened; and

133 DeP’T OF HEALTh \& HuMAN SERVs., supra note 44, at 188. 
when this happens, individuals often have to be hospitalized. ${ }^{134}$ Such hospitalizations are extremely costly episodes of care. 135 The insurer ends up paying for these ineffective drugs, and then also pays-an exorbitant amount-for the hospitalization due to the interruption in effective treatment. It is easy to see how these practices could actually end up being more expensive for insurance companies.

The high tiering of HIV/AIDS drugs on prescription drug formularies is not always cost- saving either, for two reasons. First, the interruptions these tierings cost inevitably leads to the proliferation of the HIV/AIDS virus and subsequent costly hospitalization. Second, these formularies often place the individual components of the STR drugs - that are on the highest tiers - on the lower tiers in small doses. ${ }^{136}$ If individuals with HIV/AIDS choose to go this medicallyunsafe route of purchasing all of the components of the STRs separately and in a large quantity-since each component is only on a lower cost-sharing tier in smaller doses-the cost to the insurance company can actually increase as compared to the STR on the highest tiers.

Insurance companies are just that, companies. Companies want to maximize profit. So why would they institute these practices that would not be cost-saving or even end up costing them more money? The answer is simple. These practices are actually cost-saving, although not in the way they are claimed to be. They are cost saving in that they discriminate against individuals with HIV/AIDS. These practices make health plans overly financially burdensome and medically unsafe, which works to discourage individuals with HIV/AIDS from enrolling in

\footnotetext{
134 See generally Nancy Crum, Trends and Causes of Hospitalizations Among HIV-Infected Persons During the Late HAART Era: What is the Impact of CD4 Counts and HAART Use?, 54(3) J. ACQUIR. IMMUNE DEFIC. SYNDR. 248 (2010).

135 Michael Carter, HIV Treatment is Costly, Especially for the Sickest Patients, AIDSMAP (Sept. 27, 2010), http://www.aidsmap.com/ HIV-treatment-is-costly-especially-for-the-sickest-patients/page/ 1516347, [http://perma.cc/W6V4-ACFZ].

136 Elizabeth Taylor, ACA Discrimination Against People with HIV/AIDS Will Not Be Tolerated, HuffingTon Post, (Jun. 6, 2014), [http://www.huffingtonpost.com/elizabeth-taylor/aca-discriminationagainst-hiv_b_5511810.html, [http://perma.cc/A5PX-5DC].
} 
them. Thus, the insurance companies get what they want: less people with HIV/AIDS on their plans. They are intentionally discriminating against individuals with HIV/AIDS to keep such individuals off of their plans, which saves money for the insurer.

Overall, it seems that if these insurance practices are not found to be intentionally discriminatory under $\S 504$ of the Rehabilitation Act, and thus $\S 1557$ of the ACA, then intentional discrimination is a breathtakingly narrow and rather useless standard.

\section{Disparate Impact Discrimination: Prohibited?}

In order to determine whether these insurance practices are prohibited by $\S 1557$ as disparate impact discrimination, it must first be determined whether $\S 504$ of the Rehabilitation Act - which $\S 1557$ invokes - actually prohibits disparate impact discrimination. In Alexander $v$. Choate, the State of Tennessee planned to reduce the number of inpatient hospital days per year that state Medicaid would pay hospitals for a Medicaid beneficiary's hospitalization. ${ }^{137}$ A group of Medicaid recipients filed a class action suit seeking declaratory and injunctive relief. ${ }^{138}$ Plaintiffs alleged that the reduction in days of coverage violated $\S 504$ of the Rehabilitation Act because it negatively and disproportionately affected the handicapped. The Court opined that "much of the conduct that Congress sought to alter in passing the Rehabilitation Act would be difficult if not impossible to reach were the Act construed to proscribe only [intentional discrimination]." 139 The Court refused to hold that $\S 504$ proscribes disparate impact broadly as a general rule in all cases. ${ }^{140}$ The Court's refusal to do so seemed to be fueled by a fear of a "boundless" and overly broad cause of action in $\S 504 . .^{141}$ However, the court concluded that $\S 504$ can proscribe disparate impact

\footnotetext{
137 Alexander v. Choate, 469 U.S. 287, 289 (1985).

138 Id.

139 Id. at $296-297$.

140 Id. at 299.

141 Id.
} 
discrimination in some cases, ${ }^{142}$ such as when a "[disabled] individual [is not] provided with meaningful access to the benefit that [is] offer[ed]." 143 While "fundamental" or "substantial" modifications to the program or benefit are not required, "reasonable" modifications are required. ${ }^{144}$ In fact, "under some circumstances, a refusal to modify an existing program might become unreasonable and discriminatory." 145

The Court found that Tennessee's reduction in coverage days did not violate $\S 504 .{ }^{146}$ The Court reasoned that the reduction did not disproportionately affect handicapped individuals but affected both handicapped and nonhandicapped individuals equally. ${ }^{147}$ So although the Court did not find disparate impact discrimination to have been present in Alexander v. Choate, it did recognize that $\S 504$ prohibits disparate impact discrimination in certain cases.

\section{E. High Tiering and Step-Therapy and Pre-Authorization Requirements: Disparate Impact Discrimination?}

With this legal framework in mind, it can now be determined whether high tiering and step-therapy and preauthorization requirements qualify as disparate impact of the kind prohibited under $\S 504$ of the Rehabilitation Act and thus $\S 1557$ of the ACA.

The present situation is different from that in Alexander v. Choate. In Alexander v. Choate, the reduction in coverage days was not disparate impact discrimination because it affected both handicapped and non-handicapped individuals equally since both groups of people needed equal access to hospitalization. However, in the current situation, only individuals with HIV/AIDS need access to HIV/AIDS medications. Therefore, these aforementioned insurance practices that drastically limit access to HIV/AIDS medications negatively affect individuals with HIV/AIDS whereas it does not negatively affect those without the

142 Id.

143 Id. at 301.

144 Id. at 300.

145 Id. (citing Southeastern Community College v. Davis, 442 U. S. 397 (1979)).

146 Id. at 309 .

147 Id. 
disease; in other words, it disproportionately affects individuals with HIV/AIDS. This is disparate impact discrimination.

So it is clear that disparate impact discrimination is at play here. However, recall that $\S 1557$, through $\S 504$ of the Rehabilitation Act, does not extend to all disparate impact discrimination, but only such discrimination that denies individuals with a disability "meaningful access" to the benefit offered.148 In this case, that is exactly what is happening. Insurance companies are offering the benefit of health insurance coverage for medications. However, because high tiering and step-therapy and pre-authorization requirements cause HIV/AIDS medications to be unaffordable and cause dangerous interruptions in treatment, they effectively deny individuals with HIV/AIDS the benefit of insurance coverage for their medications. These practices are such that an individual with HIV/AIDS cannot effectively manage and treat their condition, causing the plans that subscribe to such practices to be inaccessible to those with HIV/AIDS. So individuals with HIV/AIDS are being denied the very benefit that is being offered to them health insurance coverage for their medications and treatment. Such individuals are being denied meaningful access to the benefit at issue. This is precisely the form of disparate impact discrimination that the Court in Alexander v. Choate explained that the law prohibits.

Furthermore, insurance companies that subscribe to these practices need only modify their plans to a "reasonable" degree; a "substantial" or "fundamental" change in the program is not necessary. ${ }^{149}$ HIV/AIDS medications need only be dropped down to lower tiers. While these insurers may argue that this would cost too much money, it is obviously not financially debilitating considering that some insurance companies already have such medications on lower, more affordable tiers. ${ }^{150}$ Surely these other companies

$148 I d$. at 301.

149 Id. at 300.

150 See AIDS Found. of Chi., Cost of HIV Medications in the Illinois Health Insurance Marketplace (March 13, 2014) (on file with the AIDS Found. of Chi.), available at http://www.aidschicago.org/resources/ content/1/4/documents/afc-il-marketplace-hiv-med-coverage-2015.pdf/ [http://perma.cc/T4PK-3L78]. 
are not operating at a loss by putting these HIV/AIDS mediations on lower tiers; if such a formulary structure were to cause a loss, these companies would not have such formularies. The step-therapy and pre-authorization requirements would need to be completely abolished. While at first blush this may seem to be a "substantial" or "fundamental" modification, it is not. Again, this is because other companies do not impose these requirements and they are not operating at a loss. Operating without these requirements is feasible and reasonable. Furthermore, it is not an unreasonable modification for insurers to alter or even completely dispose of practices whose sole purpose is to discriminate and discourage qualified individuals from enrolling. Overall, high tiering, step-therapy, and preauthorization requirements seem to constitute the very sort of disparate impact discrimination that $\S 504$ of the Rehabilitation Act - and thus $\S 1557$ of the ACA - was interpreted by the Supreme Court to prohibit.

\section{A Policy Consideration}

With such a new, expansive, and unprecedented law as the ACA, it is wise to take a step back and at least briefly look at some of the policy considerations that may affect this situation and that courts may factor in to a decision. Section 1557 does not exist in vacuo but lives within the broader context of the entire ACA and indeed the entire health insurance market. In the introduction to this Note the key pieces of the ACA were briefly explained. The following is an explanation about how some of those pieces interact to keep the ACA afloat.

The guaranteed issue and the community rating requirements ensure that everyone, regardless of their health status or history, is functionally able to obtain health insurance at relatively similar rates. 151 However, if this were all the ACA did, health insurance rates overall would skyrocket because of all of the high-risk people entering the

151 Joel E. Miller, Healthcare Reform: The "Three-Legged Stool" of Health Insurance Reform Under the ACA, AMHCA (Oct. 1, 2013), http://www.amhca.org/news/detail.aspx?ArticleId=717 [http://perma.cc/ U66C-ZJN4]. 
market.152 However, the individual mandate, in a sense, forces most Americans to buy insurance and thus participate in the health insurance market. ${ }^{153}$ This brings low-risk individuals into the market to counterbalance the high-risk individuals and thus reduces the cost of insurance. ${ }^{154}$ Finally, the premium tax credits subsidize the cost of the insurance from low- and middle-income individuals so that it is actually feasible for them to afford the health insurance the individual mandate requires them to buy. ${ }^{155}$ This is the "three-legged stool" of the ACA; abolish or damage any one of these provisions and the ACA cannot stand. 156

We have seen that insurance companies are trying to find ways to keep out high-risk individuals -individuals with a preexisting condition - even though the ACA prohibits such practices. ${ }^{157}$ If these practices, such as high tiering, steptherapy, and pre-authorization requirements, go unchecked, it will functionally undo the key provisions of the ACA that provide for the guaranteed issue and the community requirements. Without that leg of the stool, the ACA will fall. ${ }^{158}$ One of the ACA's largest purposes will go unfulfilled. Therefore, it is imperative that $\S 1557$ be given broad scope and considerable teeth to combat these discriminatory practices and close the back door the health insurance companies have been using to elude the guaranteed issue and community rating requirements. The Supreme Court has already seemed willing to interpret portions of the ACA so that they may stand and have effect, even if not as originally intended, as opposed to completely gutting them. ${ }^{159}$ So there is some hope that the Courts will interpret $\S 1557$ favorably in upcoming cases in order to keep the ACA intact and thus keep millions of people insured.

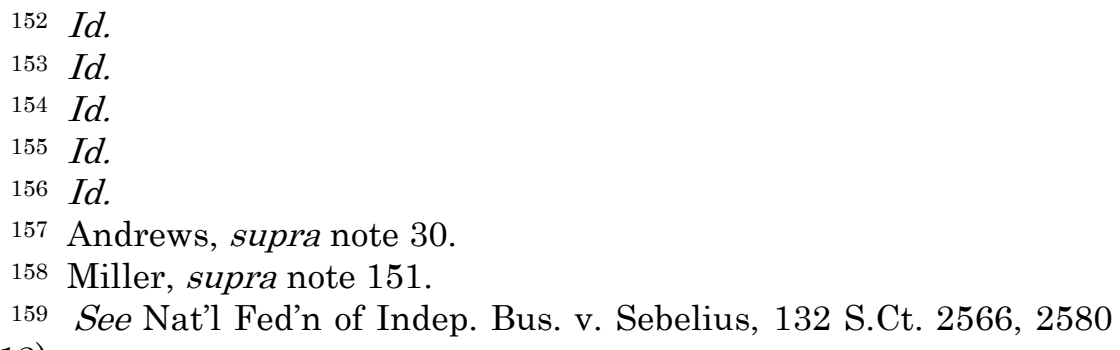




\section{CONCLUSION}

Most of the health insurance companies in the United States will be covered entities under, and thus be subject to, the regulation of $\S 1557$. Section 1557 prohibits intentional and certain forms of disparate impact discrimination against individuals with HIV/AIDS. The three health insurance practices described in this note likely qualify as the intentional discrimination prohibited by $\S 1557$ and even more likely qualify as the disparate impact discrimination prohibited by $\S 1557$. Policy also weighs in favor of $\S 1557$ prohibiting these insurance practices. Therefore, $\S 1557$ should serve as an effective means to combat discrimination by health insurance companies against individuals with HIV/AIDS in the form of the high tiering of HIV/AIDS medications on prescription drug formularies and steptherapy and pre-authorization requirements. 